J. Clin. Chem. Clin. Biochem.

Vol. 15, 1977, pp. 13-19

\title{
Kinetic Enzymatic Method for Automated Determination of Glucose in Blood and Serum ${ }^{1}$ )
}

\author{
By J. Ziegenhorn, U. Neumann, A. Hagen, W. Bablok, and K. Stinshoff \\ Boehringer Mannheim GmbH, Biochemica Werk Tutzing, Forschungszentrum, Tutzing
}

(Received June 30/September 15, 1976)

Summary: Studies are reported on the reaction kinetics of the glucose assay according to Trinder which involves the specific oxidation of glucose by glucose oxidase and the determination of the hydrogen peroxide released by means of phenol and 4-aminophenazone in the presence of peroxidase. The results have been used to develop a general kinetic fixed-time method for the analysis of glucose in whole blood and serum. The single reagent method has been adapted to the ENI GEMSAEC centrifugal analyzer and to the Abbott ABA-100 analyzer. The procedures exhibited excellent precision and the results correlated well with those obtained by the hexokinase method. Linearity was achieved from 3 to $64 \mathrm{mmol} / \mathrm{l}$ glucose for the GEMSAEC method, and from 3 to $33 \mathrm{mmol} / 1$ glucose for the ABA-100 method. Reagent or sample blank corrections were not necessary. There were no interferences from various drugs, hemoglobin, bilirubin, or lipemia.

\section{Enzymatische Methode zur Bestimmung von Glucose in Blut und Serum auf kinetischer Basis mittels Analysenauto- maten}

Zusammenfassung: Wir untersuchten die Reaktionskinetik des Glucose-Tests nach Trinder, bei dem Glucose durch Glucose-Oxidase oxidiert und das freigesetzte Wasserstoffperoxid mittels Phenol und 4-Aminophenazon in Gegenwart von Peroxidase bestimmt wird. Die Ergebnisse wurden zur Entwicklung eines allgemein anwendbaren kinetischen „fixed-time“-Verfahrens für die Analyse von Glucose in Blut und Serum benutzt. Die mit einem EinkomponentenReagenz durchführbare Methode wurde auf die Analysenautomaten ENI Gemsaec und Abbott ABA-100 adaptiert. Die einzelnen Varianten der Methode ergaben bei der Untersuchung von Präzision und Richtigkeit ausgezeichnete Resultate. Der Linearitätsbereich erstreck te sich beim GEMSAEC-Verfahren von 3 bis $64 \mathrm{mmol} / 1$ Glucose, beim ABA-100-Verfahren von 3 bis 33 mmol/1 Glucose. Die Bestimmung von Reagenz- oder Probenleerwerten war nicht erforderlich. Störungen durch verschiedene Pharmaka, Hämoglobin, Bilirubin und Lipämie wurden nicht beobachtet.

\section{Introduction}

Among the many methods for blood or serum glucose determination, the procedures based on the oxidation of glucose by glucose oxidase (EC 1.1.3.4) are perhaps most widely used in clinical laboratories (1-2):

$$
\begin{aligned}
& \beta=D \text {-Glucose }+\mathrm{H}_{2} \mathrm{O}+\mathrm{O}_{2} \stackrel{\begin{array}{l}
\text { glucose } \\
\text { oxidase }
\end{array}}{=} D \text {-glucono- } \delta \text { - } \\
& \text { lactone }+\mathrm{H}_{2} \mathrm{O}_{2}
\end{aligned}
$$

The enzyme is specific for $\beta$-glucose which comprises about $64 \%$ of total serum glucose (3). Since the

\footnotetext{
1) Presented in part at the GEMSAEC Users Club Meeting, Göteborg, Sweden, February 9-10, 1976, at the 7 th International Symposium on Clinical Enzymology, Venice, Italy, April 5-7, 1976, and at the Kongreß der Deutschen Gesellschaft fuir Laboratoriumsmedizin, Berlin, Germany, May $20-22,1976$.
}

remaining $\alpha$-glucose is converted to the $\beta$-form by mutarotation, the total glucose content of the sample is covered by that reaction (1).

The hydrogen peroxide released in the glucose oxidase reaction is commonly determined with peroxidase (EC 1.11.1.7) and a suitable hydrogen donor which is oxidized to a colored compound (1-2). In the modification according to Trinder (4), the following indicator reaction is used:

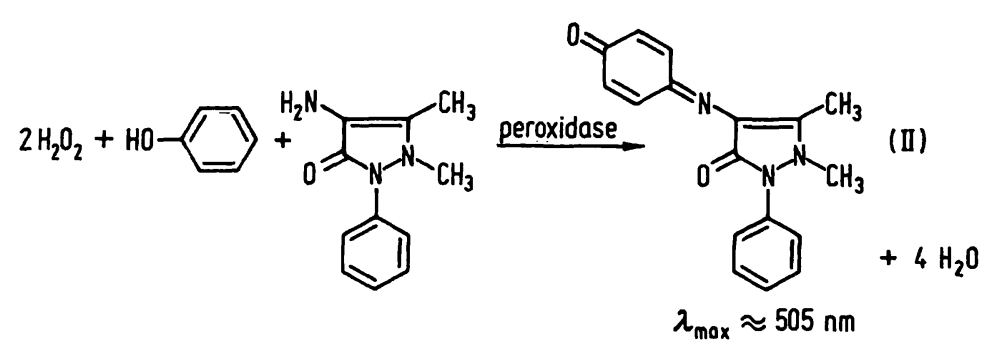


This colometric method so far has been carried out as an end-point or equilibrium procedure. Little effort appears to have been expended on the elaboration of a kinetic procedure which potentially can improve the speed, specifity and simplicity of the assay.

It is well recognized that enzymatic substrate analysis can be based on reaction rate measurements, if the Michaelis constant $K_{\mathrm{m}}$ of the enzyme is much greater than the initial substrate concentration (5). In this case, a reaction obeying pseudo-first order kinetics is obtained which can be easily measured on automated instruments by means of kinetic fixed-time methods (6). An inspection of the properties of glucose oxidase reveales (7) that this enzyme, due to its high $K_{\mathrm{m}}$-value of about $30-110 \mathrm{mmol} / \mathrm{l}$, is ideally suited for kinetic analysis of glucose.

The present study was undertaken to examine the feasibility of a kinetic procedure for glucose determination with use of the assay according to Trinder. The first step in this treatment was to analyze in detail the kinetics of the reaction system. The results obtained enabled us to develop a general kinetic fixed-time method for routine analysis of blood and serum glucose. The method has been adapted for use with two commercially available automated instruments. Each analytical approach has been characterized with respect to precision, accuracy and susceptibility to interference.

\section{Materials and Methods}

\section{Apparatus}

An ENI GEMSAEC centrifugal analyzer including ROTOLOADER (Electro-Nucleonics, 368 Passaic Ave., Fairfield, N. J. 07006), an ABA-100 analyzer (Abbott Scientific Products Division, South Pasadena, Calif. 91030), and an AutoAnalyzer I (Technicon Instruments, Tarrytown, N. Y. 10591) were used for the automated determinations. The GEMSAEC analyzer was interfaced to a DEC-PDP 8 computer and had a DECtape for additional program storage (Digital Equipment, Maynard, Mass. 01754). The manual assays were carried out on Model $1101 \mathrm{M}$ spectrum line photometers (Eppendorf Gerätebau Netheler \& Hinz, 2 Hamburg, Germany).

\section{Reagents}

Test kit "Glucose, GOD/PAP method" cat. No. 166391; test kit "Glucose, hexokinase method", cat. No. 124346; test kit "Blood sugar, GOD/PAP method", cat. No. 124001; standard "Precimat Glucose" (5.55 mmol/l D-glucose), cat. No. 125555; standard "Precimat-D Glucose" (505 $\mu \mathrm{mol} / 1$ D-glucose), cat. No. 125580; uranyl acetate solution $(3.77 \mathrm{mmol} / 1$ of physiological saline), cat. No. 125415 ; perchloric acid $(0.33 \mathrm{~mol} / \mathrm{l})$, cat. No. 125369 ; and $\alpha$-methyl-DOPA were all from Boehringer Mannheim, P. 0 . Box 51, D-6800 Mannheim 31, Germany. D-glucose, bilirubin and ascorbic acid were purchased from E. Merck, D-6100 Darmstadt, Germany. From the constituents of the test kit "Glucose, GOD/PAP method" a single reagent was prepared which contained phosphate buffer $(0.1 \mathrm{~mol} / \mathrm{I}, \mathrm{pH} 7.0)$, phenol $(11 \mathrm{mmol} / \mathrm{l})$ 4-amino-phenazone $(0.75 \mathrm{mmol} / \mathrm{l})$, glucose-oxidase $(\geqq 13 \mathrm{kU} / \mathrm{l})$, and peroxidase $(\geqq 0.8 \mathrm{kU} / \mathrm{l})$. This reagent was used for both, the kinetic procedures with the GEMSAEC or with the ABA-100 and the manual end-point procedure according to Trinder. It was stable for at least 2 months at $4^{\circ} \mathrm{C}$.
Procedures

\section{Deproteinization (1)}

$1.0 \mathrm{ml}$ of uranyl acetate solution was added to $0.1 \mathrm{ml}$ of capillary blood or serum. After careful mixing the suspension was centrifugated for $10 \mathrm{~min}$ at $3000 \mathrm{r}$. p. m. Aliquots of the supernatant were submitted to the manual endpoint procedure according to Trinder or to the automated kinetic assays.

\section{GEMSAEC}

$50 \mu \mathrm{l}$ of calibration standard $(505 \mu \mathrm{mol} / \mathrm{l})$ or deproteinized sample was pipetted into cavity $B$ of the transfer disc, followed by $150 \mu \mathrm{l}$ of physiological saline diluent; $\overline{500 \mu l}$ of reagent was pipetted into cavity $C$ of the transfer disc. The disc was placed into the GEMSAEC analyzer which was operated at a wavelength of $510 \mathrm{~nm}$ and at $25^{\circ} \mathrm{C}$. The first absorbance reading was taken $35 \mathrm{~s}$ after the start of the run (IR $=10$ ), the second reading $90 \mathrm{~s}$ later. The sample ring was loaded in the following sequence: position 1, distilled water; position 2, standard; and positions 3-16, control sera and patients' samples. There was no need for sample or reagent blanks.

Using native serum as a specimen, the procedure given above was followed. However the volume of calibration standard (5.55 $\mathrm{mmol} / \mathrm{l}$ ) and serum to be pipetted into cavity B of the transfer disc was reduced to $5 \mu$ l.

For the calculation of the results, the computer program TC $=5$ was used, which is designed for routine kinetic fixedtime analysis (Ëlectro-Nucleonics Europe, Tramșingel 39, Breda, Holland).

\section{$A B A-100$}

$50 \mu \mathrm{l}$ of calibration standard $(505 \mu \mathrm{mol} / \mathrm{l})$ or deproteinized sample and $500 \mu$ l of reagent were pipetted into the 32-place plastic cuvet. Using the light filter $500 \mathrm{~nm} / 600 \mathrm{~nm}$, the first absorbance reading was taken at $20 \mathrm{~s}$ after the initiation of the run, and the second reading was taken $300 \mathrm{~s}$ later. The incubation temperature was $37^{\circ} \mathrm{C}$. The samples in positions 0-2 were distilled water, the sample in position 3 was the standard, and the samples in positions 4-31 were control sera and patients' specimens. It was not nécessary to determine reagent or serum blanks. As with the GEMSAEC procedure the volume of standard $(5.55 \mathrm{mmol} / \mathrm{l})$ or samples was reduced to $5 \mu \mathrm{l}$ if native serum was submitted to the assay.

\section{Other procedures}

The manual glucose oxidase-based endpoint determinations were carried out as described by Trinder (4). However, $0.2 \mathrm{ml}$ of sample and $2.0 \mathrm{ml}$ of reagent were used. Moreover, the incubation was performed for $35-40 \mathrm{~min}$ at $20-25^{\circ} \mathrm{C}$, and the measuring wavelength was $\mathrm{Hg} 546 \mathrm{~nm}$. The hexokinase (EC 2.7.1.1) method was conducted as described by Bergmeyer et al. (8). The AutoAnalyzer I was operated according to the procedure of Trinder (4), using the test kit "Blood sugar, GOD/PAP method". The erythrocyte hemolysate used for the examination of hemoglobin interference was prepared as reported by Gochman et al. (9). The content of triglycerides or cholesterol of human sera was determined enzymatically as described previously $(10,11)$.

\section{Results and Discussion}

\section{Reaction Kinetics}

Figure 1 represents the time course of the overall reaction of the assay, using a semilogarithmic plot. In a plot of that kind, first- or pseudo-first-order behaviour is indicated by straight lines. The slope of these lines is proportional to the rate constant of the reaction (12). The Figure demonstrates 


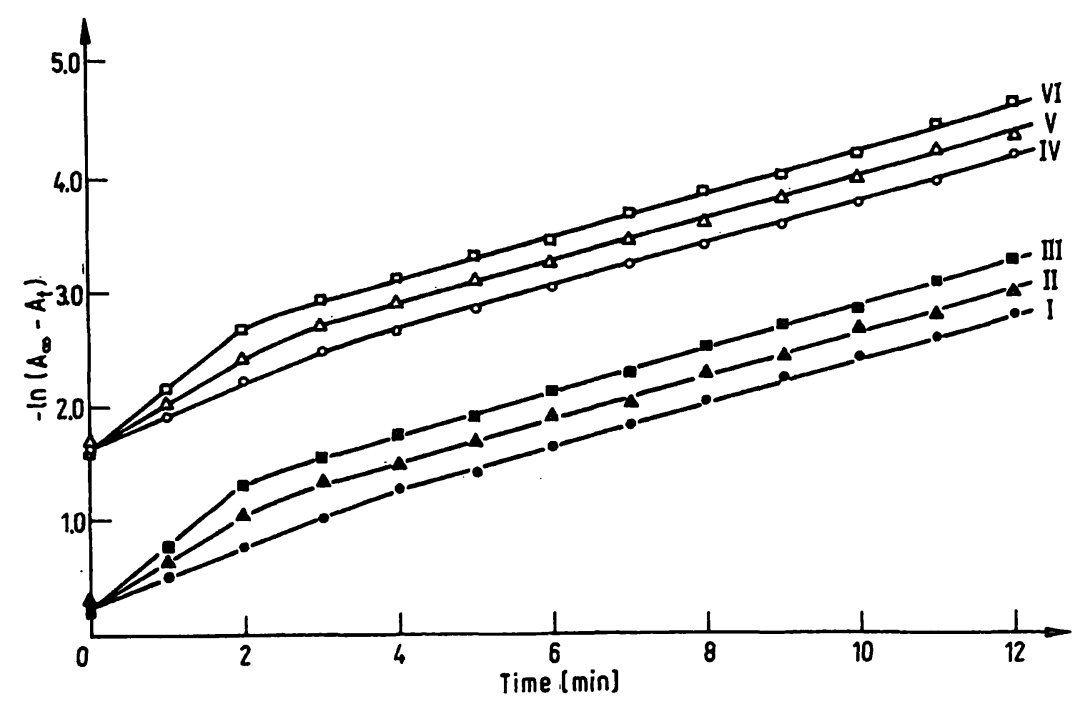

Fig. 1. Effect of glucose oxidase concentration on time course of reaction.

$A_{t}$, absorbance at time $t, A_{\infty}$, absorbance after completion of reaction. $\bullet, \circ, 13 \mathrm{kU} / 1$ glucose oxidase. $\Delta, \Delta, 23 \mathrm{kU} / 1 \mathrm{glucose}$ oxidase. $\square, 0,61 \mathrm{kU} / 1$ glucose oxidase.

Samples: Curves I-III, glucose standard (22.2 mmol/l). Curves IV-VI, glucose standard ( $5.55 \mathrm{mmol} / \mathrm{l})$. The response curves were recorded at $\mathrm{Hg} 546 \mathrm{~nm}$ through an Eppendorf photometer by simulating the GEMSAEC assay.

that the velocity of the reaction is first order overall in glucose concentration. However, the reaction displays a distinct two phase rate characteristic. It passes through a fast period in the beginning, after which it enters into a slower period.

The Figure also shows that the rate constant of the fast early stage of the reaction increases, whereas the length of this stage decreases with increasing glucose oxidase concentration. In contrast, the rate of the second portion of the reaction is not influenced by the concentration of the glucose oxidase enzyme. Figure 2 illustrates that the velocity of this reaction phase can be increased by the addition of mutarotase to the reagent. No changes in the reaction rate are to be observed if the concentration of peroxidase is increased (fig. 2).

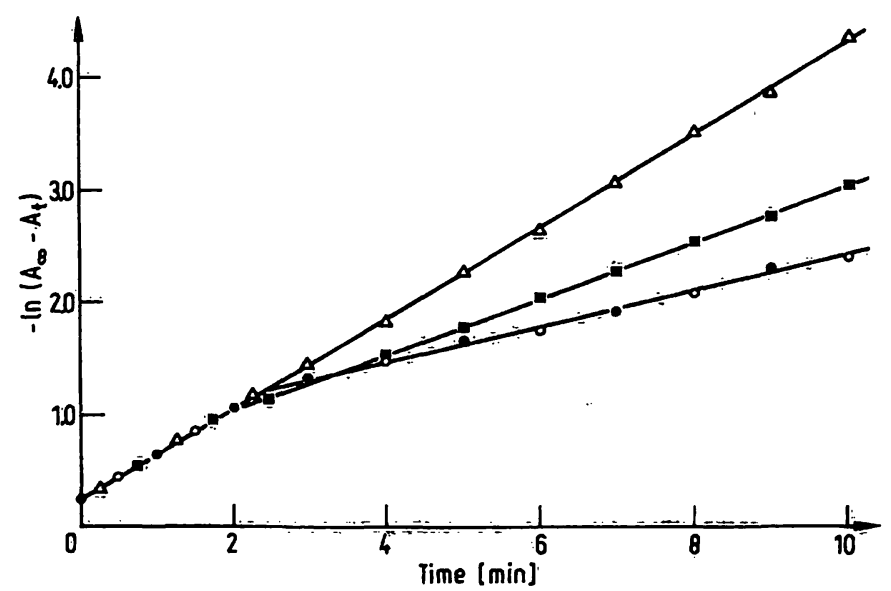

Fig. 2. Effect of added mutarotase or peroxidase concentration on time coupre of reaction.

,$- 2 \mathrm{kU} / 1$ mutarotase. $\Delta, 20 \mathrm{kU} / 1$ mutarotase. $0,0.8 \mathrm{kU} / 1$ peroxidase. $\bullet, 1.6 \mathrm{kU} / \mathrm{l}$ peroxidase.

Sample: glucose standard $(22.2 \mathrm{mmol} / \mathrm{l})$. For further details see legend of Figure 1.
We conclude from these observations that in the initial phase of the reaction, the oxidation of the $\beta$-glucose portion of the sample by glucose oxidase is the rate limiting step of the whole reaction sequence. Because of the high $K_{\mathrm{m}}$-value of the enzyme, the reaction follows pseudo-first order kinetics. After the consumption of $\beta$-glucose, the subsequent formation of this molecule from the $\alpha$-glucose portion of the sample by spontaneous mutarotation becomes rate-limiting. The exact pseudofirst-order behaviour of this isomerization process has long been recognized (3).

From the foregoing it is evident that the reaction system can be kinetically described as

$$
X \stackrel{k_{+1}}{\underset{k_{-1}}{\longrightarrow}} Y \stackrel{k_{+2}}{\longrightarrow} Z
$$

where $\mathrm{X}$ denotes $\alpha$-glucose concentration, Y $\beta$-glucose concentration, and $Z$ hydrogen peroxide concentration. $k_{+1}, k_{1}$, and $k_{+2}$ are the pseudo-first-order rate constants of the respective reactions. The following differential equations and a conservation equation can be formulated (13):

$$
\begin{aligned}
& \frac{d X}{d t}=-k_{+1} X+k_{-1} Y \\
& \frac{d Y}{d t}=k_{+1} X-k_{-1} Y-k_{+2} Z \\
& \frac{d Z}{d t}=k_{+2} Y \\
& Z=X_{0}+Y_{0}-X-Y
\end{aligned}
$$

Here $X_{0}$ and $Y_{0}$ are the initial concentrations of $\alpha$-glucose and $\beta$-glucose, respectively. At time $t=0, Y_{0}=K X_{0}$, 
where $\mathrm{K}$ is the equilibrium constant of the mutarotation process.

To solve the differential equations $1-3$ we applied the method of Laplace transformation with reference to Rescigno et al. (13) and Bronstein et al. (15): Utilizing the Laplace transforms $\mathrm{X}, \mathrm{y}$, and $\mathrm{z}$ of $\mathrm{X}, \mathrm{Y}$, and $\mathrm{Z}$ equations 1-3 become

$$
\begin{aligned}
& s x-X_{o}=-k_{+1} x+k_{-1} y \\
& s y-Y_{o}=k_{+1} x-k_{-1} y-k_{+2} y \\
& s z-Z_{o}=k_{+2} y
\end{aligned}
$$

The equations can be rearranged to give

$$
\begin{aligned}
& \left(s+k_{+1}\right) x-k_{-1} y=X_{0} \\
& -k_{+1} x+\left(s+k_{-1}+k_{+2}\right) y=Y_{0} \\
& -k_{+2} y+s z=0
\end{aligned}
$$

where $s$ is a real or a complex number.

The solution of this system of equations is

$$
\begin{aligned}
& x=\frac{D_{1}}{D} \\
& y=\frac{D_{2}}{D} \\
& z=\frac{D_{3}}{D}
\end{aligned}
$$

in which $\mathrm{D}$ is the determinant of the coefficient matrix and $D_{i}(i=1,2,3)$ are determinants obtained from $D$ by replacing the i-th column by the column of constant terms, i. e. the right-hand side of the above system of equations. It is assumed that $D \neq 0$. By setting $a+b=k_{+1}+k_{-1}$ $+k_{+2}$ and $a b=k_{+1} k_{+2}$ one obtains

$$
\begin{aligned}
& D=s(s+a)(s+b) \\
& x=\frac{X_{0} s+X_{0}\left(k_{-1}+k_{+2}\right)+Y_{0} k_{-1}}{(s+a)(s+b)} \\
& y=\frac{Y_{0} s+X_{0} k_{+1}+Y_{0} k_{+1}}{(s+a)(s+b)} \\
& z=\frac{Y_{0} k_{+2} s+X_{0} k_{+1} k_{+2}+Y_{0} k_{+1} k_{+2}}{s(s+a)(s+b)}
\end{aligned}
$$

Application of the reverse Laplace transformation to equations $15-17$ and subsequent rearrangement yields the final solutions

$$
\begin{aligned}
X & =\frac{1}{b-a}\left\{\left[X_{o}\left(b-k_{+1}\right)+Y_{0} k_{-1}\right] e^{-a t}\right. \\
& \left.-\left[X_{0}\left(a-k_{+1}\right)+Y_{0} k_{-1}\right] e^{-b t}\right\} \\
Y & =\frac{1}{b-a}\left\{\left[X_{0} k_{+1}-Y_{0}\left(a-k_{+1}\right)\right] e^{-a t}\right. \\
& \left.-\left[X_{0} k_{+1}-Y_{0}\left(b-k_{+1}\right)\right] e^{-b t}\right\}
\end{aligned}
$$

$$
\begin{aligned}
Z & =X_{0}+Y_{0}-\frac{1}{b-a}\left\{\left[X_{0} b+Y_{0}\left(b-k_{+2}\right)\right] e^{-a t}\right. \\
& \left.-\left[X_{0} a+Y_{0}\left(a-k_{+2}\right)\right] e^{-b t}\right\}
\end{aligned}
$$

Equation 20 can be used to calculate the change in concentration $Z$ during the fixed-time interval $\Delta t=t_{2}-t_{1}$. The result indicates (equation 21) that

$$
\begin{aligned}
\Delta Z=Z_{2}-Z_{1}=\frac{1}{b-a}\{ & \left\{b\left(e^{-a t_{1}}-e^{-a t_{2}}\right) \quad(\text { eq } 21)\right. \\
& \left.-a\left(e^{-b t_{1}}-e^{-b t_{2}}\right)\right] X_{0} \\
+ & {\left[\left(b-k_{+2}\right)\left(e^{-a t_{1}}-e^{-a t_{2}}\right)\right.} \\
- & \left.\left.\left(a-k_{+2}\right)\left(e^{-b t_{1}}-e^{-b t_{2}}\right)\right] Y_{0}\right\}
\end{aligned}
$$

$\Delta Z$ is a linear combination of the initial glucose concentrations $X_{0}$ and $Y_{0}$. Because $Y_{0}=\bar{K} X_{0}, \Delta Z$ is directly proportional to the total amount of glucose, providing the reading times $t_{1}$ and $t_{2}$, the terms $k_{+1}, k_{-1}$ and $k_{+2}$, resp. $a$ and $b$ are held constant during the measurement. All of these requirements can be easily achieved on automated instruments. Since two moles of $Z$ are rapidly converted to one mol of absorbing product (II), the absorbance change measured during any selected fixedtime interval is also a linear function of the initial glucose concentration. For these reasons, the kinetic fixed-time approach could be applied successfully to the assay system.

\section{Characterization of Methods}

\section{Linearity}

The linearity of the automated methods was checked by measuring a series of aqueous glucose standards which had been prepared using weighed quantities of highpurity $\bar{D}$-glucose. The results observed with use of the GEMSAEC method are shown in figure 3 . The linearity extended up to a concentration of $64 \mathrm{mmol} / 1$ glucose. The Figure also demonstrates that the sensitivity of the procedure in the normal range was reasonable. The upper limit of linearity for the ABA-100 method was $33 \mathrm{mmol} / \mathrm{l}$ glucose.

\section{Precision}

Data on the within-run precision of the present methods are provided in table 1 . The results illustrate the good reproducibility of each procedure. Day-to-day precision was determined by assaying two lots of the control serum "Precilip" (Boehringer Mannheim) during 10 days. The glucose content of this serum was 5.42 or $4.80 \mathrm{mmol} / 1$. We found a coefficient of variation of $2.6 \%$ for the GEMSAEC method, and a value of $2.9 \%$ for the ABA- 100 method, if deproteinized sera were analyzed. Without deproteinization, we obtained $\mathrm{CV}$-values of $3.4 \%$ and $3.2 \%$ for the respective method. 


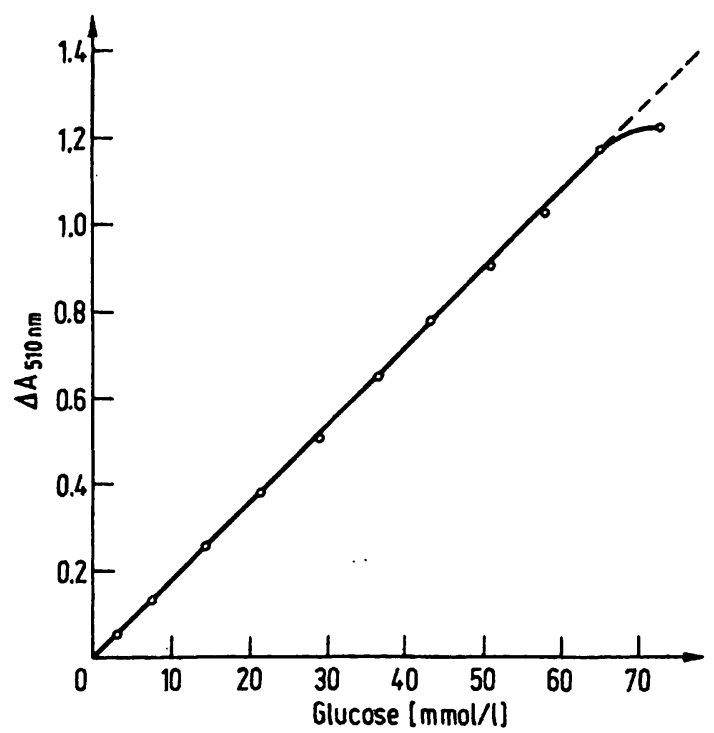

Fig. 3. Fixed-time absorbance change as a function of glucose concentration (with the GEMSAEC).

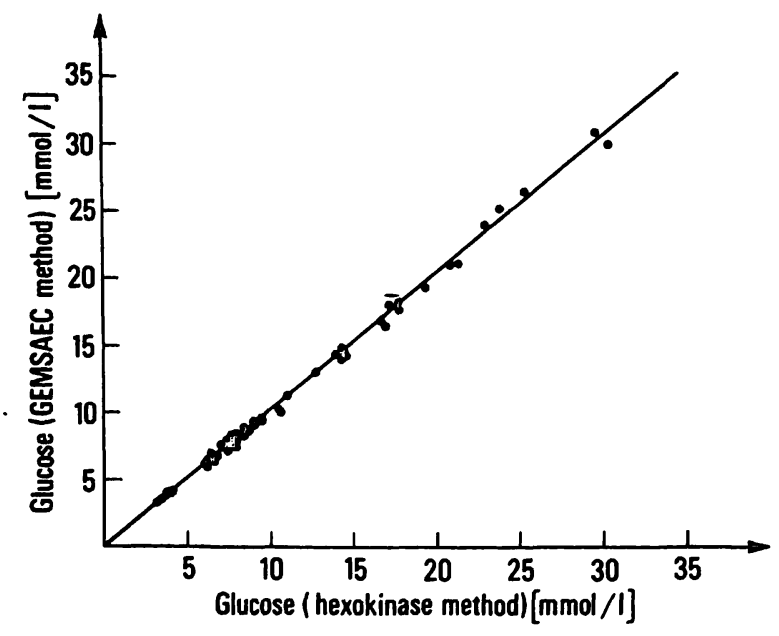

Fig. 4. Comparison of present GEMSAEC method (y) with manual hexokinase method $(x)$ for glucose in deproteinized human sera.

The samples were deproteinized with uranyl acetate (GEMSAEC method) or with perchloric acid (hexokinase method). $n=54 ; y=1.02 x-0.033 ; 95 \%$ confidence interval of slope: 1.00 to $1.03 ; 95 \%$ confidence interval of $y$ intercept: -0.23 to $0.17 . \mathrm{r}=0.999$; mean $\overline{\mathrm{x}}=11.6$; mean $\bar{y}=11.8$.
Tab. 1. Within-run precision of present methods.

\begin{tabular}{lllcll}
\hline Method & Sample & $N$ & $\begin{array}{c}\text { Glucose } \\
\text { X } \\
\text { [mmol/1] }\end{array}$ & s & $\begin{array}{l}\text { CV } \\
\text { [\%] }\end{array}$ \\
\hline GEMSAEC & Serum $^{\mathrm{a}}$ ) & 14 & 4.27 & 0.0444 & 1.0 \\
& Serum $^{\mathrm{a}}$ ) & 14 & 17.8 & 0.155 & 0.87 \\
& Serum $^{\mathrm{a}}$ ) & 14 & 45.6 & 0.433 & 1.0 \\
& Serum & 14 & 5.01 & 0.0611 & 1.2 \\
& Serum & 14 & 15.8 & 0.133 & 0.84 \\
& Serum & 14 & 37.5 & 0.511 & 1.4 \\
ABA-100 & Serum $^{\mathrm{a}}$ ) & 24 & 3.70 & 0.0500 & 1.4 \\
& Serum $^{\mathrm{a}}$ ) & 24 & 5.44 & 0.105 & 1.9 \\
& Serum $^{\mathrm{a}}$ ) & 24 & 16.6 & 0.233 & 1.4 \\
& Serum & 24 & 2.29 & 0.0722 & 3.2 \\
& Serum & 24 & 4.80 & 0.150 & 3.1 \\
& Serum & 24 & 29.9 & 0.416 & 1.4 \\
\hline
\end{tabular}

a) With deproteinization.

\section{Accuracy}

The glucose concentration of deproteinized human sera was determined by the automated kinetic methods and, in parallel, by the manual hexokinase reference method (8). The results of these correlation studies were excellent (fig. 4 and 5). Likewise satisfactory linear regression parameters were obtained if capillary blood was used as the sample instead of senim (fig. 6). In this case, two different samples were takèn from each patient. After deproteini= zation, one sample was submitted to the kinetic assay and the other one to the hexokinase method; the coefficient of correlation obtained was lower than in the preceding studies. However, the slope and the y-intercept of the regresssion curve were within the $95 \%$ confidence limits. Moreover, a paired t-test showed no significant difference between the results obtained by the two methods $(t=0.84$, critical $t=2.23$ at $95 \%$ confidence limits).

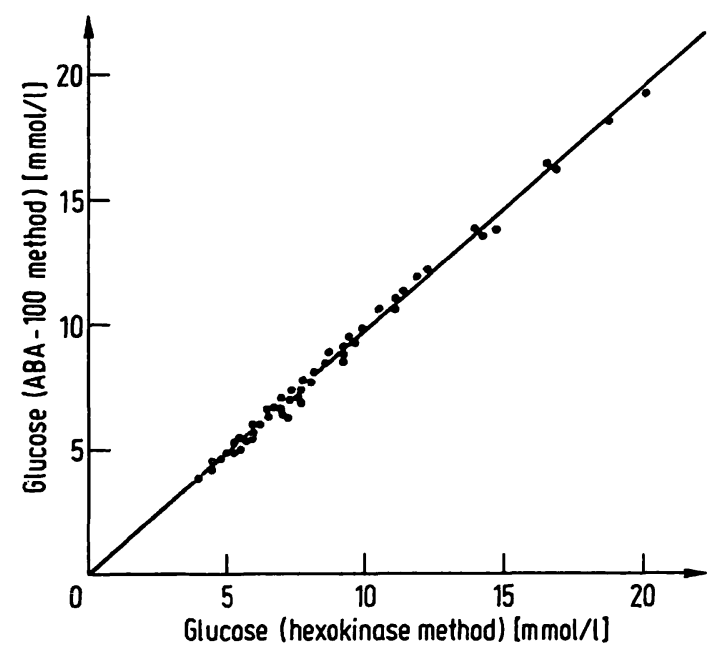

Fig. 5. Comparison of present ABA-100 method (y) with manual hexokinase method $(x)$ for glucose in deproteinized human sera.

The samples were deproteinized with uranyl acetate (ABA-100 method) or with perchloric acid (hexokinase method). $n=60 ; y=0.98 x-0.077 ; 95 \%$ confidence interval of slope: 0.96 to $0.99 ; 95 \%$ confidence interval of $y$-intercept: -0.26 to $0.10 ; r=0.997$; mean $\bar{x}=8.66$; mean $\bar{y}=8.41$.

Figures 7 and 8 illustrate that the kinetic assay can also be successfully applied to native human sera. However, it must be noted that in this instance the measured values are generally $6-11 \%$ higher than those obtained for the sera after deproteinization. The molecular basis for this obvious decrease of serum glucose concentration on deproteinization is still under investigation. 


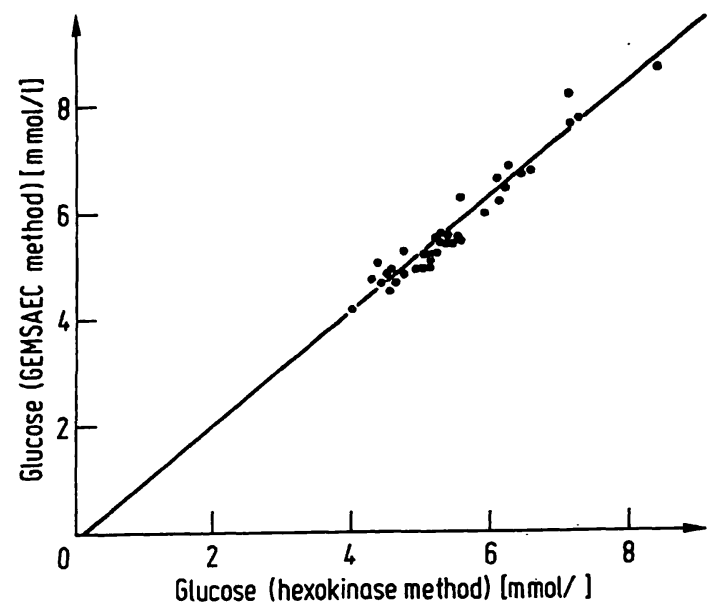

Fig. 6. Comparison of present GEMSAEC method (y) with manual hexokinase method (x) for glucose in capillary blood samples.

The samples were deproteinized with uranyl acetate (GEMSAEC method) or with perchloric acid (hexokinase method). $\mathrm{n}=39 ; \mathrm{y}=1.05 \mathrm{x}-0.19 ; 95 \%$ confidence interval of slope; 0.96 to $1.14 ; 95 \%$ confidence interval of $y$-intercept: -0.69 to $0.31 ; r=0.969$; mean $\overline{\mathrm{x}}: 5.55$; mean $\overline{\mathrm{y}}: 5.64$.

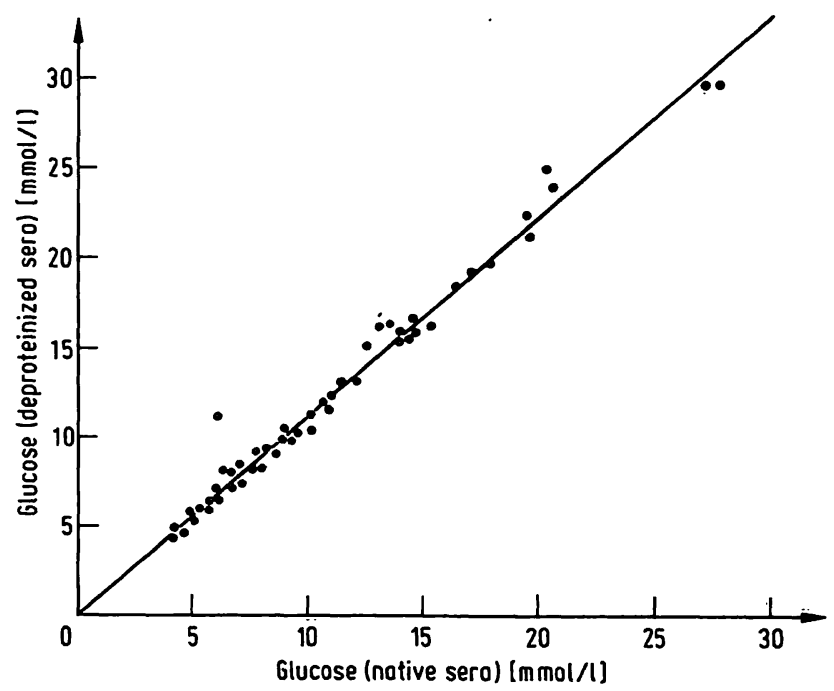

Fig. 7. Relation between glucose values obtained by the GEMSAEC method for human sera before and after deproteinization.

Native sera $(y)$. Sera deproteinized with uranyl acetate (x). $n=50 ; y=1.10 x+0.067 ; 95 \%$ confidence interval of slope: 1.07 to $1.14 ; 95 \%$ confidence interval of $y$ intercept: -0.33 to $0.47 ; \mathrm{r}=0.991$; mean $\overline{\mathrm{x}}=10.1$; mean $\bar{y}=11.2$.

\section{Interferences}

Drug interferences with glucose end-point methods have been discussed in detail by Szasz et al. (14). These authors demonstrated that out of 43 representative drugs only ascorbic acid, novaminsulfonic acid, and $\alpha$-methyl-DOPA are a potential source of errors in the

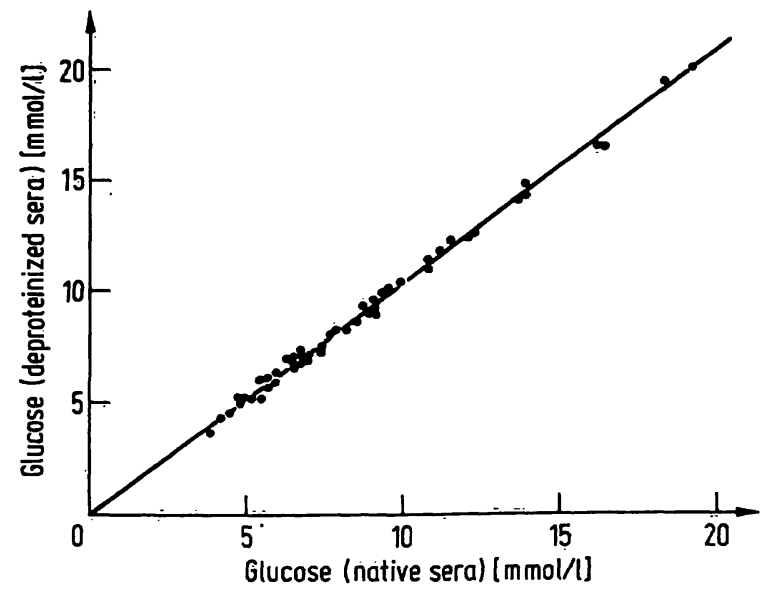

Fig. 8. Relation between glucose values obtained by the ABA-100 method for human sera before and after deproteinization. Native sera $(y)$. Sera deproteinized with uranyl acetate (x). $n=60 ; y=1.04 x+0.16 ; 95 \%$ confidence interval of slope: 1.03 to $1.06 ; 95 \%$ confidence interval of $y$-intercept: 0.013 to $0.31 ; \mathrm{r}=0.998 ;$ mean $\overline{\mathrm{x}}: 8.38 ;$ mean $\overline{\mathrm{y}}: 8.88$.

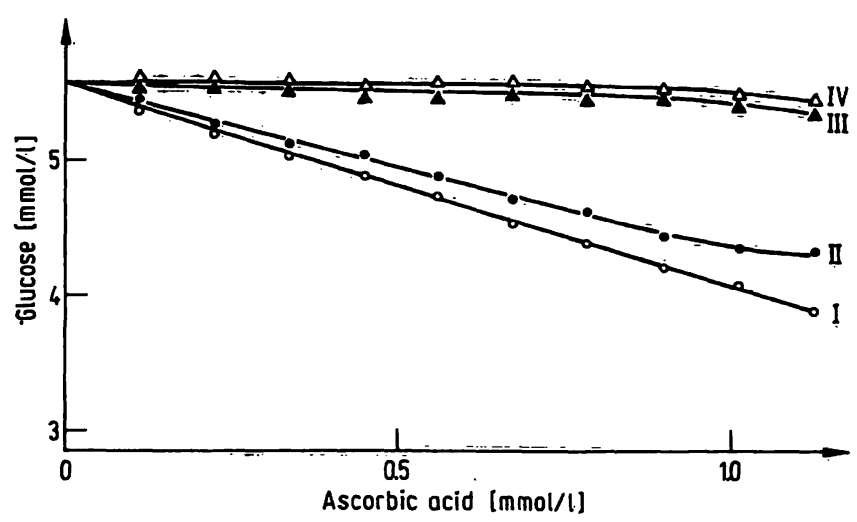

Fig. 9. In vitro interference of ascorbic acid with some glucose assays according to Trinder.

AutoAnalyzer I method (I). Manual end-point method (II). GEMSAEC method, sera deproteinized with uranyl acetate (III). GEMSAEC method, native sera (IV).

glucose assay according to Trinder. These drugs were shown to cause a significant decrease in glucose values measured by the end-point procedure, if they had been added in vitro to human sera. Only small and almost negligible effects, however, were observed in the corresponding in vivo experiments.

When examining the in vitro influence of the above drugs on the kinetic assay, we obtained results like those shown in Figures 9 and $10^{2}$ ). One important observation to make here is that the kinetic approach is to a much less subject to drug interferences than the manual end-point procedure or the AutoAnalyzer I procedure. Differences in the velocity of the competitive reactions between substrates and drugs must be the reason for this effect. The data suggest that there is no in vivo drug interference with the kinetic method.

2) These measurements were done by $E$. Munz and $R$. Walker in our laboratory. 


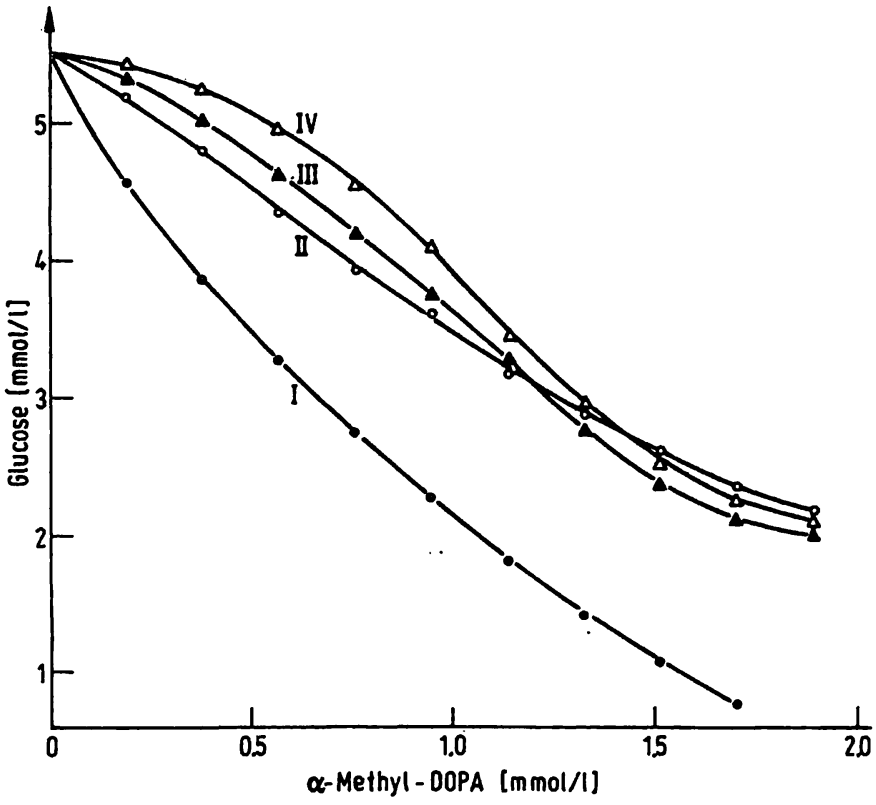

Fig. 10. In vitro interference of $\alpha$-methyl-DOPA with some glucose assays according to Trinder.

Manual end-point method (I). AutoAnalyzer I method (II). GEMSAEC method, sera deproteinized with uranyl acetate (III). GEMSAEC method, native sera (IV).

Tab. 2. Effect of added bilirubin or hemoglobin on the glucose value of a human serum, as measured by the GEMSAEC method.

\begin{tabular}{lll}
\hline $\begin{array}{l}\text { Bilirubin added } \\
{[\mu \mathrm{mol} / 1]}\end{array}$ & $\begin{array}{l}\text { Hemoglobin added } \\
{[\mu \mathrm{mol} / 1]}\end{array}$ & $\begin{array}{l}\text { Glucose found } \\
{[\mathrm{mmol} / 1]}\end{array}$ \\
\hline- & - & 6.61 \\
34.2 & - & 6.66 \\
85.5 & - & 6.38 \\
171 & - & 6.77 \\
- & 13.8 & 6.55 \\
- & 55.1 & 6.22 \\
- & 110 & 6.49 \\
\hline
\end{tabular}

a) Mean values of duplicate determination.

\section{References}

1. Bergmeyer, H. U. \& Bernt, E. (1974), in Methods of Enzymatic Analysis (Bergmeyer, H. U., Ed.) Vol. 3, 1205-1215, Academic Press, New York, London.

2. Bernt, E. \& Lachenicht, R. (1974), in 1. c. (1), 1215-1222.

3. Pigman, W. \& Anet, E. F. L. J. (1972), in The Carbohydrates Chemistry and Biochemisțy (Pigman, W. \& Horton, D., Eds.) Vol. IA, 165-194, Academic Press, New Yörk, London.

4. Trinder, P. (1969), Ann. Clin. Biochem. 6, 24-27.

5. Bergmeyer, H. U. (1974), in Methóds of Enžymatic Analysis (Bergmeyer, H. U., Ed.) Vol. 1, 131-134, Academic Press, New York, London.

6. Ingle, J. D. \& Crouch, S. R. (1971), Anal. Chem. 43, 697-701.

7. Bergmeyer, H. U., Gawehn, K. \& Grassl, M. (1974), in Methods of Enzymatic Analysis (Bergmeyer, H. U., Ed.) Vol. 1, 425=522, Academic Press, New York, London.
Tab. 3. Analytical recovery of glucose added to lipemic human sera by use of GEMSAEC method.

\begin{tabular}{|c|c|c|c|c|c|c|}
\hline & $\begin{array}{l}\text { Tri- } \\
\text { glyce- } \\
\text { rides } \\
\text { nmol/1] }\end{array}$ & $\begin{array}{l}\text { Chol- } \\
\text { esterol }\end{array}$ & $\begin{array}{l}\text { Al- } \\
\text { ready } \\
\text { pre- } \\
\text { sent }\end{array}$ & $\begin{array}{l}\text { Glucose }^{\mathrm{a}} \text { ) } \\
\text { [mmol/1] } \\
\text { Added }\end{array}$ & Found & $\begin{array}{l}\text { Re- } \\
\text { covery } \\
\text { [\%] }\end{array}$ \\
\hline $\begin{array}{l}1 \\
2 \\
3 \\
4 \\
5\end{array}$ & $\begin{array}{c}4.29 \\
1.99 \\
10.5 \\
9.02 \\
2.53\end{array}$ & $\begin{array}{c}4.97 \\
7.19 \\
11.8 \\
8.12 \\
10.3\end{array}$ & $\begin{array}{l}5.33 \\
5.44 \\
5.99 \\
5.05 \\
4.99\end{array}$ & $\begin{array}{l}11.5 \\
16.6 \\
27.9 \\
39.0 \\
50.2\end{array}$ & $\begin{array}{l}16.9 \\
21.5 \\
34.6 \\
44.6 \\
56.5\end{array}$ & $\begin{array}{r}100 \\
98 \\
102 \\
101 \\
102\end{array}$ \\
\hline
\end{tabular}

a) Mean values of duplicate determination.

To study the influence of colored blood constituents, such as bilirubin or hemoglobin on the kinetic assay, we added different amounts of these substances to a human serum pool and measured the glucose concentration without deproteinization of the samples. The results obtained make it obvious (tab. 2) that these substances do not cause any interference in the assay. In addition, no interference was found from lipemia. This is illustrated by the result of analytical recovery studies from lipemic human sera supplemented with known quantities of pure glucose (tab. 3).

\section{Conclusions}

Our data show that the kinetic method described here is more specific than the corresponding manual end-point procedure or the AutoAnalyzer I procedure. Also, it affords a higher sample through-put because of shorter analysis time. Since the determination of a sample blank can be omitted the suggested method is convenient and reagent costs are low.

\section{Acknowledgements}

We thank Mrs. D. B. Grosse, Miss H. Hoffmann, and Miss D. Schwenk for excellent technical assistance.

8. Bergmeyer, H. U., Bernt, E., Schmidt, F. \& Stork, H. (1974), in l. c. (7) Vol. 3, 1196-1201.

9. Gochman, N., Ryan, W. T., Sterling, R. E. \& Widdowson, G. M. (1975), Clin. Chem. 21, 356-361.

10. Ziegenhorn, J. (1975), Clin. Chem. 21, 1627-1629.

11. Ziegenhorn, J. (1975), this J. 13, 109-115.

12. Hewitt, T. E. \& Pardue, H. L. (1973), Clin. Chem. 19, $1128-1134$.

13. Rescigno, A. \& Segre, G. (1966), Drug and Tracer Kinetics, 75-91, Blaisdell Publishing Company, Waltham, Mass.

14. Szasz, G., Huth, K., Busch, E. W., Koller, P. U., Stähler, F. \& Vollmar, J. (1974), this J. 12, 256.

15. Bronstein, I. N. \& Semendjajew, K. A. (1958), Taschenbuch der Mathematik, 393-397, B. G. Teubner Verlagsgesellschaft, Leipzig.

Dr. J. Ziegenhorn Boehringer Mannheim $\mathrm{GmbH}$ Biochemica Werk Tutzing

Forschungszentrum Postfach 120

D-8132 Tutzing 
.

.

